\title{
Putting it Right? The Labour Party’s Big Shift on Immigration Since
}

\section{0}

TIM BALE

\section{Abstract}

Under pressure from voters, and from other parties, Europe's centre-left has had to reevaluate its position on migration. The UK Labour party is no exception. Public concern about large-scale immigration clearly contributed to its heavy defeat at the 2010 general election. Since then it has been slowly but surely hardening its stance on the issue, although this is by no means unprecedented: while the rise of UKIP may have upped the ante in recent months, Labour has a long history of adjusting policy in this area so as to remain competitive with its main rival, the Conservative party. Labour is now asking itself whether it will be possible to do this without challenging one of the fundamental precepts of EU membershipthe right of free movement of people. Whatever the result of this internal debate between the Party's 'beer drinkers' and its 'wine drinkers', Labour may still have difficulty in neutralising immigration as an issue since, for the most part, it continues to insist on giving an essentially economic answer to what for many voters is actually a cultural question.

It is not only Europe's conservative, market-liberal and Christian Democratic parties who are struggling to come up with some kind of response to the threat posed by radical right-wing populist parties. Indeed, in a number of countries it is clear that social democratic and labour parties have suffered almost as much as, and in some cases possibly more than, their rivals on the centre-right. After all, populist parties that successfully push an antiimmigration message increase the salience of an issue that has rarely done the left many 
favours electorally. They also appeal strongly to working class voters who traditionally support the left. And in countries where single party majority administrations are the exception rather than the rule, they may well help the centre-right into office, either by joining it in coalition or by providing support on confidence and supply to a minority government.

Left-of-centre responses to this 'triple challenge' vary considerably, both between countries and over time; but they can be effectively reduced to the following three idealtypical strategies. ${ }^{1}$ The left-of-centre can try to hold its existing, relatively liberalinternationalist position by unashamedly making the case for tolerance of migration and multiculturalism. Or it can try to defuse the situation by trying to play down the issues championed by the radical right in favour of those issues (normally on the so-called 'statemarket' dimension) which favour the centre-left. Or else it can adopt the radical right's agenda and hope to close down the issue space on the other ('authoritarian-libertarian') dimension by arguing that migration must be limited and multiculturalism tempered by an increased emphasis on 'integration'; that done, politics can, fingers crossed, get back to 'normal'.

In the real world, of course, these strategies bleed into one another, although more often than not hold gives way to defuse, which then gives way to adopt, especially when a centre-left party feels the radical right might cost it not only votes but also office. Moreover, none of the strategies is risk-free. The first attracts accusations that the party has lost touch and the second that it is refusing to listen and even running away from a fight. The third strategy courts criticism (internal and external) for being illiberal, inauthentic and incredible. Moreover, it risks not only further raising the profile of issues which are already benefiting the radical right, but also taking time and attention away from issues that it may be more profitable for the centre-left to emphasise — a possibility that Labour's election strategists are 
acutely aware of. However, with less than a year to go before the country goes to the polls, the party is still conflicted about how to deal with immigration and with UKIP. Both policy and rhetoric have been tightened but some are arguing that Labour has to go further-even so far as to challenge some of the basic principles of the European order that the party has bought into for the past quarter of a century.

\section{Labour Past: Balancing Act}

For most of its history, the Labour party has been untroubled by a radical right competitor, except for brief periods in the 1970s and 2000s when first the National Front and second the British National Party won a few seats from it at second-order elections. This has never, however, prevented Labour from worrying about immigration-maybe even more so (or at least for longer) than many of its sister parties in Europe. Ever since the late 1950s, the Conservatives have sought to suggest that they, rather than Labour, best represent public opinion on the issue - opinion which is for the most part ambivalent and at times actively hostile. As a result, Labour has, since the 1960s, sought to effect a balance between controlling the numbers of migrants settling in the UK-often incurring intense criticism from liberal commentators and its own progressive supporters as a consequence - and promoting, often through legislation, equality for ethnic minorities. That approach, which contrasted markedly with the Tories' more hard-line rhetoric and policies, saw Labour garner the overwhelming support of the UK's growing Black and Minority Ethnic (BME) population. But it left the Conservatives with a large and durable lead on the issue in opinion polls, albeit not one which (with the possible exception of the 1970 contest) ever looked capable of helping them to win an election they might otherwise have lost. ${ }^{2}$ 
The balancing act that had characterised Labour's stance on immigration since the 1960s broke down, however, after 1997, when a government that was already notably more relaxed about the issue than its predecessors decided not to impose transitional controls on workers from the eight states which joined the EU in 2004. As a consequence, the UK experienced an unprecedentedly intensive and utterly unplanned wave of immigration, particularly (though by no means exclusively) from Eastern and Central Europe. Realising that it was in trouble, the Labour government - under pressure from the Conservatives and from the country's predominantly right-wing print media—reacted by toughening its stance on asylum and immigration, both in word and in deed. ${ }^{3}$ Its efforts, however, were in vain or were even positively counterproductive. Concern about the influx of foreigners and the apparent pressure that their presence put on public services in some parts of the country not only boosted the electoral fortunes of the UK Independence Party (UKIP) but, along with the country's economic problems, appear to have played a big part in Labour losing the general election of $2010 .^{4}$

\section{Labour Present: 'It's the economy, stupid.'}

Since its defeat and its loss of office to the Conservative-Liberal Democrat coalition, Labour has been audibly crunching through the gears, trying — as many other left-of-centre parties in Europe have tried - to preserve elements of its traditional liberalism (hold), to insist on the primacy of the cost of living (defuse) and to shift to a perceptibly more restrictive position $(a d o p t)$. The internal debate about its stance, however, has only got louder, especially following UKIP's stunning performance in local and European elections in the spring of 2014. At those elections - boosted perhaps by the low turnout and by what some argued was the disproportionate media coverage afforded to its leader, Nigel Farage - the so-called 
'People's Army' showed it could take seats from Labour as well as the Tories by appealing to white, poorly educated, often badly off voters who live in the party's heartlands and who feel 'left behind' by social, economic and cultural change and unrepresented by any of the mainstream political parties. ${ }^{5}$

To listen some of those Labour MPs who, in the wake of the results (and much to the delight of right-wing media outlets), rushed onto the airwaves and into print to insist that the leadership act on the concerns of their voters who had switched to UKIP, one would have thought that Ed Miliband and co. had maintained some sort of radio silence on immigration for the previous four years. Nothing, however, could be further from the truth. The subject was aired during the Labour leadership contest (initially, but only initially, by Ed Balls)— hardly surprisingly, since so many of those voting in the contest had heard it raised again and again on the doorstep during the general election, and then read about the role it played in the party's defeat in all the instant analyses of the campaign. It therefore came as no great shock when, in his very first party conference speech as leader, Ed Miliband—making it clear he was speaking to the whole country, not just the audience in the hall—said: 'You wanted your concerns about the impact of immigration on communities to be heard, and I understand your frustration that we didn't seem to be on your side.' And he went further: Labour, he suggested, by seeming to imply that anyone concerned about the issue (not least about the impact of immigration on wages) was prejudiced, was 'failing to serve those who we are in politics to represent' ${ }^{6}$

A year later — after Miliband's favourite 'Blue Labour' guru, Maurice Glasman, controversially stirred the pot by suggesting that Labour had not only lied about the numbers of migrants coming in but had deliberately used the influx as a means of controlling working people's wages - both Labour's leader and its Shadow Home Secretary, Yvette Cooper, were back at conference admitting, in the words of the latter, that 'We did get things wrong on 
immigration'. ${ }^{7}$ Not for the first time, the biggest mistakes acknowledged were the decision not to impose transitional controls on new member states in 2004 and the failure to bring in a points-based system earlier. More generally, Cooper argued: 'Managed migration has benefits for our economy and our culture, but we also need to recognise its impact on communities. And that means strong, fair controls that are properly enforced. ${ }^{8}$ The same themes were at the heart of Ed Miliband's heavily trailed speech on the subject to IPPR in late June $2012 .{ }^{9}$ But so too was the argument that, just as it had been wrong not to admit the costs as well as the benefits of immigration and to appear to be telling those who lost out to 'like it or lump it', it was equally wrong to pretend to people that 'we can close Britain off from the world, when all of us know we cannot'. Indeed, what Miliband really wanted to do (as well as slipping in a passing mention that the party might decide to keep the government's 'cap' on numbers, as well as reintroduce exit checks) was to move the argument onto what was, for him anyway, far more comfortable territory. What was needed, he claimed, was, first, to introduce 'tougher labour standards to do more to protect working people from their wages and conditions being undermined' and, second, to begin turning Britain into an economy that invested in its existing human capital and technology rather than simply sucking in low-skilled foreign labour.

As well as illustrating the possibly predictable tendency for a social democratic party to come up with an economic answer to what for many voters is largely a cultural question (and therefore a much harder one to answer), Miliband's speech was also notable for its explicit assumption that Labour could and would do nothing about free movement of labour for EU citizens. This in spite of the fact that this is a) precisely what got the Blair and Brown government's into such trouble and b) precisely why the current government, even in the unlikely event that it were to be able to cut non-EU immigration 'from the hundreds to the 
tens of thousands', would still be unable to do much about immigration overall—something which UKIP, of course, never misses an opportunity to point out.

This was clearly still the position when Yvette Cooper made her (first) 'big speech' on immigration in March 2013 - one which began (apparently without a trace of irony) with yet another ritual nod to immigration not only placing 'stresses and strains' on communities, but also being 'one of those difficult subjects politicians don't talk about'. After ticking a few more familiar boxes (the importance of not entering 'an arms race of rhetoric on immigration', the need for 'a serious debate' and 'practical measures', etc. etc.), Cooper did then make a move onto more cultural terrain by talking about English tests and integration strategies. But she swiftly shifted back (after another quick nod to the possibility of maintaining the cap) toward economic territory, outlining a series of specific new regulations and fines on employers of immigrants. More audaciously, however, she ended by attempting to outflank the Tories on cracking down on illegal immigrants and on EU migrants' access to financial support from the welfare state, in particular claims for jobseeker's allowance and the (to most people ridiculous) law that allows workers to get UK child benefit for their offspring living abroad. ${ }^{10}$

All this was echoed in another speech to the IPPR by Labour's then Shadow Minister on Immigration, Chris Bryant, later in the summer-but with a new twist. ${ }^{11}$ At the time, what grabbed the headlines was some embarrassing and, it turned out, erroneous criticism of some major British retailers contained in a briefed copy of the speech. But it was what was between the lines that was actually far more interesting. For the first time a Labour spokesman, albeit without going into detail of what precisely needed changing, seemed to be calling for a reconsideration of the hitherto inviolable right of free movement, not just for citizens of countries which might in the future join the EU (which Cooper herself had done) but for citizens of countries which were already member states. 
The extent to which such a move was needed - in the sense of the right of free movement effectively undermining any attempt by the party (and indeed the coalition) to match the public's preferences on immigration —was almost immediately illustrated when, going into the 2013 party conference season, Labour announced its intention to legislate to oblige companies wanting to hire a skilled worker from outside the EU to train a British apprentice as well. Not only did this attract the ire of the business lobby, it was also rapidly ridiculed by journalists who, briefed by government spokesmen, pointed out that, legally, any such apprenticeships would in fact have to be opened up to citizens right across the EU (and, if one really wanted to be picky, Iceland, Liechtenstein and Norway too). In this atmosphere it was perhaps understandable that Cooper did not choose in her speech to develop Bryant's point. Instead, she relied on her audience's contempt for the government's 'Go Home vans', as well as the fact that most of the measures designed to signal Labour's intention to reduce immigration focused on unscrupulous employees, agencies, landlords and gangmasters, in order to drum up support for measures on restricting welfare benefits that, in isolation, might have proved a little trickier, at least for some liberals. ${ }^{12}$ In a set-piece article on immigration in the New Year of 2014, Miliband did exactly the same thing, focusing on the party's plans to close what he called 'the low wage loophole' and 'race to the bottom' that supposedly encouraged businesses to hire people from abroad rather than the UK. ${ }^{13}$

At that stage, the idea that UKIP might do some serious electoral damage to Labour as well as the Conservatives was only in its infancy. But by the time Cooper got up to deliver another major speech on immigration at the beginning of the campaign for the 2014 European and local elections in which Nigel Farage's outfit was widely predicted to knock the Opposition into second place, this idea was gaining ground - thanks in part to the efforts of academics Rob Ford and Matt Goodwin. Perhaps as a result, Cooper ratcheted things up. 
Triangulating with the best of them, Cooper insisted (once again) that she wanted 'an open honest debate that doesn't promote hostility but doesn't ignore concerns' and to show how what she now called Labour's 'progressive immigration policy' differed both from 'a traditional conservative approach' ('all immigration is bad'/'we can build a wall and hide behind it') and from 'a free-market liberal approach' ('views all migration as good and tries to open all the doors' $/$ immigrants as a source of innovation, but also as cheap labour to keep wages and inflation low'). Then, after going over what Labour had already promised on wages and exploitation (with the addition of a promise of a consultation exercise with business, unions and communities) and on controls (with the addition of a promise to bring back finger-printing of illegal immigrants caught at Calais), she made, for the first time, a definite commitment to keep the Coalition's cap on skilled workers (although also to remove students from the net migration target), as well as a pledge that under Labour, 'all public sector workers who work directly with the public will have to be able to speak English to a decent standard'. And she finished with two new tough promises: first, there was what now seemed to be a serious commitment to 'pursuing reforms in Europe so that child tax credit and child benefit are no longer paid to families abroad'; second, there was a commitment to changing the rules so that EU citizens found guilty of assault, burglary or robbery are deported even if sentenced for less than a year. ${ }^{14}$

Her speech may have been positively received in some quarters, but it appeared to make little no difference to the worrying number of Labour voters who deserted the party for UKIP on 22 May. Their desertion duly prompted an outbreak of public and private soulsearching within the party about what more it could (or according to some, must) do in response. Miliband's was to make a heavily trailed speech in Thurrock, one of Labour's target seats where it clearly seemed to have lost support to UKIP. In it, he outlined all the changes he had made to tighten Labour's immigration policy in response to public concern 
which, he stressed, was not prejudiced but understandable. However, Labour under his leadership would not 'make false promises, or cut ourselves off from the rest of the world because it would be bad for Britain'. ${ }^{15}$

Publicly, Cooper's response was to produce, for the Guardian, a boiled-down version of her pre-election immigration speech. ${ }^{16}$ Yet there was plenty of seemingly well-informed speculation among journalists that she was among a number of frontbenchers wanting to see Labour turn up the volume on the issue. Another was her husband, Ed Balls. As Shadow Chancellor, Balls had not revisited the most radical (but at the time little noticed) part of the argument he had first raised during the Labour leadership contest, namely that 'Europe's leaders need to revisit the Free Movement Directive, not to undermine the union, but to make it economically and politically sustainable'-something that meant not only removing the right to send child benefit and tax credits abroad (which by now had become Labour policy) but also 'debating what labour protections and restrictions on unskilled labour mobility are needed in an enlarging Europe, for the benefit of all European peoples' ${ }^{17}$ Now, four years later, his call suddenly seemed remarkably prophetic.

On 1 June seven Eurosceptic Labour MPs wrote an open letter to Miliband, calling on him 'to commit the next Labour government, as part of any serious renegotiation of our relationship with the EU, to constraining the free movement of labour from European countries with much lower incomes, thereby removing some of the pressure on wages, welfare, housing and public services in this country. Above all', they continued, 'such a move would prove to voters that we are intent on regaining control of our own borders'. ${ }^{18}$ This stood in marked contrast to the advice offered to Miliband in a newspaper article by two famously Blairite former ministers, Alan Milburn and John Hutton, and in a radio interview by Blair himself. According to Labour's former leader: 'Of course you have got to have proper controls on immigration, you have to deal with those parts of the immigrant 
community that are rejecting the idea of integrating into the mainstream, but to allow that then to trend into anti-immigrant feeling is a huge mistake.' He insisted that 'the way to deal with UKIP is to stand up to them and take them on. What they are putting before people is a set of solutions that anybody who analyses where Britain has to be in the 21 st century knows... are regressive, reactionary and [will] make Britain's problems worse, not better.' Should Labour move towards Farage's 'anti-European' and 'anti-immigrant platform', he continued, then 'all that will happen is that it will confuse its own supporters and will not draw any greater support'.

It is tempting when talking about Labour post-1997 to analyse these differences through the prism of the 'TB-GBs', and to see those urging Miliband not to compromise on Labour's support for freedom of movement as Blairites and those urging him to think again as Brownites. Indeed, it may not be altogether wrong. After all, it was Blair who believed that the British had to be made ready for globalisation rather than protected against it, while it was Balls who helped keep the UK out of the single currency and Brown who once promised 'British jobs for British workers' — even if he did later go on, during the 2010 general election, to label a member of the public who had expressed her concerns about immigration 'a bigoted woman'. But that is not the whole story - at least, not for everyone involved in the debate. Anyone reading the names of the seven MPs who signed the open letter to Miliband calling for a reform of freedom of movement would be hard pressed to call them a Brownite cabal. Likewise Chris Bryant, although associated with attempts to get Blair to stand down as Prime Minister, was not a hard-core, long-term supporter of his successor, and backed David rather than either of the two Eds in the leadership campaign.

By the same token, although he famously resigned from the Blair government and only made a return when Brown took over, and although he voted for Ed Miliband in the leadership contest, it would be unfair to paste the Brownite label onto perhaps the most senior 
Labour figure to have nailed his colours to the mast on immigration in the wake of the party's defeat to UKIP in May 2014. On 2 June, John Denham, due to retire as MP for Southampton Itchen in 2015 and previously charged by Miliband with helping Labour to win back seats in the South, wrote an forthright piece on the subject for the increasingly popular LabourList blog. ${ }^{19}$

Denham began by making the (historically accurate) points that 'There is nothing in Labour history, values or traditions that requires us to be in favour, in principle, of unlimited immigration' and that the Blair government had not operated an 'open door' policy. He moved on to make the point (a controversial but entirely logical one, given the fact that the UK's points-based system makes no room for low-skilled migrants from outside Europe) that '[m]any of the EU citizens who are entitled to come here are people we would reject if they came from anywhere else'. Next he made the even more controversial point that 'we should work actively to reduce the number of EU migrants coming to the UK, and move closer to the relationship we have with the rest of the world', reminding readers that this was what Labour's 'current policies - clamping down on dodgy agencies, enforcing minimum wage, requiring apprenticeships, tackling unregulated housing - are designed to do', only 'we are so politically correct we cannot admit that's the aim, even though that's exactly what most of our voters want to hear'. Those voters, he asserted, were not so much racist as bewildered by the pace of change, took a common-sense view that more people coming in put more pressure on scarce public resources (especially when it came to housing) and expected Labour-the party that was supposed to be about fairness and rewarding contribution - to be 'on their side'. Labour's traditional commitment to a multiracial, multicultural society did not have to mean it ignored the need for integration and nation-building. Nor did its continued commitment to EU membership mean that it could not lead the debate in Europe about changing the rules on free movement. 
Denham's views were promptly attacked by the Labour's liberal progressives — whose opinions, given that they also reflect those of many of the NGOs and academics who specialise in migration, have to be taken seriously, especially by a party that claims to take evidence-based policy making seriously. ${ }^{20}$ And, whatever the private views of some Shadow Ministers, 'the line to take', for the moment at least, remained the one faithfully repeated by Denham's successor as Shadow Business Secretary, Chuka Umunna, at a conference the weekend after the European election results were announced: namely that there was no future or point in Labour trying to 'out-UKIP UKIP', nor was there any question of resiling from free movement in the EU. ${ }^{21}$ Ed Miliband, then, seems determined to hold the ring between on the one hand those who think that promising voters Labour can negotiate some sort of labour market protection for UK citizens is bound to end in tears and, on the other, those who believe - albeit reluctantly — that in the absence of such promises, Labour is going to find it awfully difficult to hold onto some of its white working-class vote.

\section{Labour Future: Hard lines?}

How long Miliband will be able to hold this line - to mediate between what in some continental social democratic parties are called the 'beer drinkers' (concerned to maintain the party's appeal to the white working class) and 'the wine drinkers' (who believe the future is liberal, not regressive) - is a moot point. One thing, though, is certain. Whether he can or can't will not depend solely on UKIP. Labour's shift on immigration since 2010, after all, has been largely driven not by Nigel Farage (who it only really began to worry about towards the latter half of 2013) but by its concern about the threat the issue poses in the hands of the Conservative party in Whitehall, Westminster and the media. UKIP may still fade, although not because, as some Labour optimists naively believe, those tempted to vote for it are put off when its policies on the NHS or tax are 'exposed': after all, as Ford and Goodwin make clear, the voters in question simply don't care anywhere near as much about those issues as they do 
about immigration, and anyway they don't trust Labour to deliver on them either. But if UKIP does fade, that will not necessarily mean Labour stops tightening its stance between now and the next election. The party — quite rightly — was worried before UKIP ballooned, and it will continue to worry — again quite rightly_even if it bursts. Public concern is at least in part driven by numbers as well as by political debate, and the numbers coming into the country, whether from inside or outside the EU, are not going down anything like fast enough to reassure people that things are now fully under control.

The Conservatives' lead over Labour on immigration had, according to the pollster YouGov, shrunk from twenty-nine points just after the election to just nine points at the end of May 2014. Whether this was due more to Labour's shifting position or to the fact that the government has so far proved palpably unable to deliver the real difference it promised on the issue is impossible to tell. But the Tories' election advisor, Lynton Crosby, infamous in Australia for using migration to his paymasters' advantage, is unlikely to be happy to leave it there. Anyone inclined to think that he might should look at how the government is making a great deal these days of its determination to enforce the minimum wage so as to end the exploitation of low-wage workers, thereby rendering redundant one of Labour's favourite solutions to the influx of migrant workers. They should also read the Sun. George Osborne took time out from campaigning at the Newark by-election to talk to one of its political staff for a story that ran on 1 June 2014. In the course of their chat, '[h]e vowed the Tories would put tougher curbs on EU migrants at the heart of plans to redraw our ties with Brussels. And he hinted that could see the European Union's founding principle of free movement torn up'. Not only that: the Chancellor also felt obliged to warn voters that 'if Labour win power next year the floodgates will swing back open'. That, at least, is one accusation that Miliband and his colleagues can never allow to go unchallenged. Thurrock won't be Labour's last word on 
immigration, though whether it will be the beer drinkers or the wine drinkers who have that last word remains to be seen.

\section{Notes}

${ }^{1}$ T. Bale, C. Green-Pedersen, A. Krouwel, K. R. Luther and N. Sitter, (2010) 'If you can't beat them, join them? Explaining social democratic responses to the challenge from the populist radical right in Western Europe', Political Studies, vol. 58, no. 3, 2010, pp. 410-26.

2 D. T. Studlar, 'Policy voting in Britain: the colored immigration issue in the 1964, 1966, and 1970 general elections', American Political Science Review, vol. 72, no. 1, 1978, pp. 4664.

${ }^{3}$ See T. Bale, D. Hough and S. Van Kessel, 'In or out of proportion? Labour and social democratic parties responses to the radical right', in J. Rydgren (ed.), Class Politics and the Radical Right, Routledge, 2012

${ }^{4}$ G. Evans and K. Chzhen, 'Explaining voters' defection from Labour over the 2005-10 electoral cycle: leadership, economics and the rising importance of immigration', Political Studies, vol. 61, no. S1 (2013), pp. 3-22.

${ }^{5}$ R. Ford and M. J. Goodwin, Revolt on the Right: Explaining Support for the Radical Right in Britain, Routledge, 2014.

${ }^{6}$ http://www.telegraph.co.uk/news/politics/ed-miliband/8791870/Labour-Party-ConferenceEd-Milibands-speech-in-full.html

${ }^{7}$ See http://www.progressonline.org.uk/2011/04/19/labour-isnt-working/ and http://www.telegraph.co.uk/comment/columnists/maryriddell/8644334/Labours-antiimmigration-guru.html 
${ }^{8}$ http://www.telegraph.co.uk/news/politics/labour/8794008/Labour-Party-Conference-YvetteCoopers-speech-in-full.html

${ }^{9}$ http://www.politics.co.uk/comment-analysis/2012/06/22/ed-miliband-s-immigrationspeech-in-full

${ }^{10}$ http://www.politics.co.uk/comment-analysis/2013/03/07/yvette-cooper-s-immigrationspeech-in-full

${ }^{11}$ http://www.newstatesman.com/politics/2013/08/chris-bryants-speech-immigration-full-text 12 http://press.labour.org.uk/post/62234261174/yvette-cooper-mps-speech-to-labour-party$\underline{\text { annual }}$

${ }^{13}$ http://www.independent.co.uk/voices/comment/well-close-this-unfair-lowwage-loophole9039081.html

${ }^{14}$ http://labourlist.org/2014/04/yvette-coopers-immigration-speech-full-text/

15 http://press.labour.org.uk/post/86997808779/britain-needs-real-change-not-false-promises$\underline{\text { ed }}$

${ }^{16}$ http://www.theguardian.com/commentisfree/2014/may/28/not-pretend-worried$\underline{\text { immigration-ukip }}$

${ }^{17}$ http://www.theguardian.com/commentisfree/2010/jun/06/ed-balls-europe-immigrationlabour

${ }^{18}$ http://labourlist.org/2014/06/labour-mps-write-to-miliband-urging-limit-on-free$\underline{\text { movement-from-europe/ }}$

${ }^{19}$ http://labourlist.org/2014/06/home-truths-on-migration/

${ }^{20}$ http://labour-uncut.co.uk/2014/06/03/at-least-ukips-eu-and-immigration-policies-areconsistent-john-denham-cant-even-manage-that/ For the academic evidence base, see, for example, the various contributions assembled by www.cream-migration.org, especially What do we know about immigration?, 19 May 2014. 
${ }^{21}$ http://www.theguardian.com/commentisfree/2014/may/30/labour-immigration-ukip-farage 